\title{
Book review: Ziekten van vissen, schaal-, en schelpdieren, van belang voor de Nederlandse aquacultuur
}

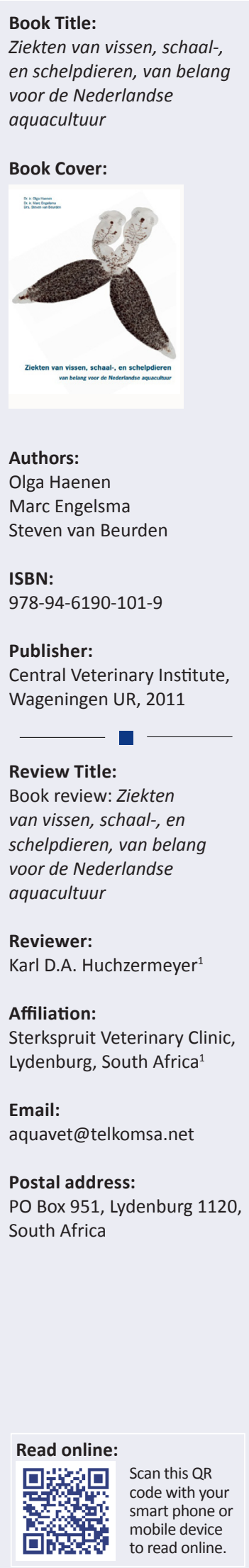

This book provides a well-laid-out overview of the diseases of fish, crustaceans and molluscs. Although aimed at aquaculture in the Netherlands, much of the information is useful for students and aquatic animal veterinarians in other countries. The systematic layout of the text makes for easy reading and as a reference work, it is easy to find relevant information on diseases. This book provides new insights into well-established diseases as well as providing up-to-date information on new diseases.

The introductory sections of the book provide a useful and well-balanced insight into aquaculture and the many factors that may impact on aquatic animals and underlie infectious disease outbreaks. The chapter titled 'Signaleren van ziekteproblemen' (signalment of disease) highlights the important role of stress in both infectious and non-infectious disease outbreaks in aquatic animals. Frequent reference is made to current European Union (EU) regulations, an interesting point being that EU regulations require aquaculture concerns to include aquatic animal veterinarians in their management plans. General approaches to the diagnosis of aquatic animal diseases are discussed, including sedation, anaesthesia and euthanasia. Therapy and the judicious use of medication under veterinary control are also discussed concisely.

Three chapters are devoted to a systematic description of infectious diseases in fish, crustaceans and molluscs respectively. The essential details of each disease, including the infectious agent, host range, geographic distribution, symptoms, diagnostic methods and transmission and prevention are covered for each disease. Relevant notification requirements in cases of an outbreak according to the World Organisation for Animal Health (OIE) guidelines and EU legislation are provided. Many of the diseases are illustrated with excellent photographs and illustrations.

A significant number of diseases covered in these chapters occur in the marine environment. With the growth in mariculture in South Africa, awareness of these diseases is particularly important. One short chapter is devoted to zoonoses. Further chapters cover EU guidelines governing aquaculture and the diagnostic procedures followed by the Central Veterinary Institute in Lelystad. Information in both of these chapters is relevant to South African veterinary authorities and our veterinary laboratories.

Aquaculture is growing rapidly worldwide. The continuing appearance of new diseases in an increasing range of cultured aquatic animals requires a high level of understanding of disease by all persons involved in the farming of these animals. The book provides relevant information needed by producers and veterinarians alike. The book is written in Dutch, which limits its readership outside of the Netherlands. Nevertheless, it is a useful book and much of the information it contains is relevant to other countries. Afrikaans speakers should not have difficulty in reading the text.

How to cite this book review: Huchzermeyer K.D.A., 2013, 'Book review: Ziekten van vissen, schaal-, en schelpdieren, van belang voor de Nederlandse aquacultuur'84(1), Art. \#1016, 1 page. http://dx.doi.org/10.4102/jsava.v84i1.1016

Note: The book is not for sale, but it can be downloaded from: http://www.wageningenur.nl/nl/Expertises-Dienstverlening/Onderzoek sinstituten/central-veterinary-institute/Expertisegebieden-Central-Veterinary-Institute/Dierziekten/Vis-en-schelpdierziekten.htm Copyright: () 2013. The Authors. Licensee: AOSIS OpenJournals. This work is licensed under the Creative Commons Attribution License. 